\section{Sorption of Methylene Blue Dye from Aqueous Solution Using an Agricultural Waste}

\section{Abstract}

Millions of tons of prickly (peel) bark of cactus fruit (PBCF) are produced per year. This work is to use this agricultural waste as a low cost biomaterial for the treatment of water contaminated with organic pollutant. PBCF has been characterized by several analytical techniques i.e. SEM, EDS and FTIR spectroscopy. In addition, the determination of iodine value which gives information on area surface. PBCF were used to remove Methylene blue (MB) from the aqueous solution. Experiments were carried out as function of contact time, initial dose of $\mathrm{PBCF}$, initial $\mathrm{pH}$ aqueous solution, initial concentration of $\mathrm{MB}\left(90-2000 \mathrm{mg} \mathrm{L}^{-1}\right)$, and temperature $\left(20-40^{\circ} \mathrm{C}\right)$. The pseudo-second-order was the best applicable model to describe the sorption of MB by Prickly bark of cactus fruit. The equilibrium sorption data of Methylene blue by Prickly barks of cactus fruit were analysed by Langmuir and Freundlich models. The preliminary results indicate that the Langmuir model provides the best correlation of the experimental data with an important capacity of sorption of Methylene blue onto Prickly bark of cactus fruit $\left(222.22 \mathrm{mg} \mathrm{g}^{-1}\right)$. Moreover the parameters of the Freundlich model showing that the sorption of MB onto PBCF is favourable. Finally, the sorption capacity of PBCF is compared to those of other sorbents materials reported in the literature.

Keywords: Sorption; Basic dye; Bio-sorbent; Isotherms; Agricultural waste

Received: April 12, 2017; Accepted: May 02, 2017; Published: May 08, 2017

\section{Seghier Abdelkarim", Hadjel Mohammed ${ }^{1}$ and Benderdouche Nouredine ${ }^{2}$}

\section{Department of Industrial Organic} Chemistry, University of Science and Technology - Mohamed BOUDIAF of Oran, Oran, Algeria

2 Laboratory of Structure, Elaboration and Application of Molecular Materials (SEA2M), University of Mostaganem, Mostaganem, Algeria

\section{Corresponding author:}

Seghier Abdelkarim

झ krimouvert@yahoo.fr, abdelkarim.
seghier@univ-usto.dz

Laboratory of Sciences, Technologies and Process Engineering, Department of Industrial Organic Chemistry, Faculty of Chemistry, University of Science and Technology - Mohamed BOUDIAF of Oran, BP 1505 El Mnaouar, Bir El Djir 31000 Oran, Algeria.

Tel: +213 542161512

\section{Introduction}

Dyes have been excessively released into the environment due to rapid industrialization and have created a major global concern. They are chemical compounds which can connect themselves to surfaces or fabrics to impart colour. The majority of dyes are complex organic molecules and are required to be resistant to many things such as the action of detergents [1]. They are often found in industrial wastewaters, which originate from textile, leather tanning, paper, cosmetics, plastics, rubber, food processing, manufacturing and printing dye activities [1].

Removal of dyes from industrial wastewater is an important problem due to the characteristics of these dyes, as that they are non-degradable and therefore persistent [2]. Moreover, most of the pollutants are toxic to living organisms and they have a large influence on the photosynthetic activity in aquatic biota [3]. To respect the environmental norms, the toxic materials should be removed from wastewater before its disposal [4].

Methylene blue is one of the most dyes found in the waters discharged by industrials activities and histologic microbiologic [5]. Severe toxicity is imposed by this pollutant: toxicity in premature
Citation: Abdelkarim S, Mohammed H, Nouredine B. Sorption of Methylene Blue Dye from Aqueous Solution Using an Agricultural Waste. Trends Green Chem. 2017, 3:1.

neonate [5] and toxicity on the central nervous system [6]. To deal with the problems caused by the dyes including Methylene Blue, several studies were devoted to their elimination such as: adsorption on activated carbon [7-9], coagulation/flocculation $[10,11]$, poly-electrolyte promoted [12,13], ozonation [14], nano-filtration [15-17], photo-catalytic degradation in advanced oxidation process $[18,19]$, electrochemical treatment $[20,21]$ and biological treatment in particularly enzyme [22-31].

According to the literature, adsorption on activated carbon remain among the most and easy technical to implement [32]. Several studies have been carried out in this area, namely: cotton [33], corn [34], silk worm cocoon [35]. 
However, the activation (chemical or physical) of carbon increases the cost of treatment; also their regeneration is a delicate operation [36].

To this end, new biomaterials subject of much research in recent years such as the adsorption of Methylene Blue on biomaterial using cactus tree [2]. As yet this technique was not applied to prickly bark of cactus fruit (peel), hence never reported in the literature according to our knowledge.

\section{Experimental}

In this work prickly bark of cactus fruit was used as bio sorbent. The raw material was dried in sunlight for 15 days at an average daylight temperature of $40^{\circ} \mathrm{C}$, watched several times with distilled water, dried at $40^{\circ} \mathrm{C}$, grounded to powder and sieved conserving only particles having a seize not exceeding $315 \mathrm{~nm}$. The product obtained noted (PBCF). To study the morphology of the PBCF surface its structure was observed using a HIROX SH $400 \mathrm{M}$ SEM-EDS BRUKER apparatus. To detect the functionality present in (PBCF), FTIR spectroscopy studies using the PerkinElmer Spectrum Two FTIR with UATR sampling accessory. The sorption capacity of materials to the dyes can be examined by calculating the iodine value [37]. Generally adsorbents with a high iodine number have a high surface area and are suitable for adsorbing small compounds [37]. For this propose the PBCF surface area was studied by measuring their iodine number $\left(\mathrm{mg} \mathrm{g}^{-1}\right)$ according to the standard procedure [38] by using the $0.1 \mathrm{~N}$ standardized iodine solution. Sample volumes of $100 \mathrm{ml}$ of the iodine solution were treated with $1 \mathrm{~g}$ of the material. After equilibrium, the remaining iodine in the supernatants was titrated with $0.1 \mathrm{~N}$ sodium thiosulfate solution. The lodine Number was reported as the amount of iodine adsorbed per gram of adsorbent at a residual iodine concentration of $0.02 \mathrm{~N}$.

The $90 \mathrm{~g} / \mathrm{L}$ concentration Methylene blue solution (initial $\mathrm{pH}$ ) used to determine the equilibrium contact time. Batch process was carried out at $20 \pm 2^{\circ} \mathrm{C}$ (ambient laboratory temperature). $25 \mathrm{ml}$ of Methylene blue solution was separately mixed with $0.1 \mathrm{~g}$ of the Prickly bark of cactus fruit (PBCF). The mixtures were put into the shaking batch (400 rev/min shaking rate) during different time intervals, ranging from 10 to $360 \mathrm{~min}$, then the solids particles were removed by centrifugation then the Methylene blue concentration in aqueous solution was determined with a SPECORD 200 PLUS -ANALYTIK, JENA- UVvisible spectrophotometer at $664 \mathrm{~nm}$ using a cuvette of $10 \mathrm{~mm}$ wide. The sorption capacities of MB onto PBCF were calculated by [39]:

\section{$q_{t}=\left(C_{0}-C_{e}\right) v / W$}

Where $q_{t}$ is the sorption capacity $\left(\mathrm{mg} \mathrm{g}^{-1}\right)$ at any time; $\mathrm{C}_{0}$ and $\mathrm{C}_{\mathrm{e}}(\mathrm{mg}$ $\left.\mathrm{L}^{-1}\right)$ are respectively the initial and final adsorbate concentration; $\mathrm{V}$ is the volume of the aqueous solution (L); $\mathrm{W}$ is the mass of the bio sorbent used $(\mathrm{g})$.

Under the same operating conditions (initial $\mathrm{pH}$, ambient laboratory temperature and $400 \mathrm{rpm}$ shaking rate), effect of PBCF mass on MB percentage removal at $100 \mathrm{mg} \mathrm{L}^{-1}$ and $0.05-0.3$ $\mathrm{g}$ of adsorbent were studied.
Effect of $\mathrm{pH}$ was investigated by mixing $0.1 \mathrm{~g}$ of PBCF with 25 $\mathrm{ml}$ Methylene blue solution ( $250 \mathrm{mg} \mathrm{L}^{-1}$ ), $\mathrm{pH}$ of the medium was adjusted to 4-12. The mixtures were stirred during contact time obtained from kinetic study at $400 \mathrm{rpm}$ and ambient laboratory temperature.

The isotherm of bio sorption experiments were performed in a rotary shaker at $400 \mathrm{rpm}$ using $250 \mathrm{ml}$ Erlenmeyer flasks containing $25 \mathrm{ml}$ of different $\mathrm{MB}$ concentrations at initial $\mathrm{pH}$. After 60 min of contact (according to the kinetic study), with $0.1 \mathrm{~g}$ PBCF biomass, the concentrations of MB equilibriums and sorption capacities were determined by the same methods and devices already reported beforehand (kinetics study).

These isotherms were studied for temperatures of 20,30 and $40^{\circ} \mathrm{C}$.

\section{Results and Discussion}

\section{Characterization of the bio-sorbent}

Following SEM image represented by Figure 1, the surface of Prickly bark of cactus fruit is full of cavities distributed on a heterogeneous surface. Similar morphology was on the external surface for cactus tree [2]. Moreover and according the literature $[3,37,40]$, this sorbent has a high surface area view its great iodine index value reaches $436 \mathrm{mg} \mathrm{g}^{-1}$. The elemental composition of the material in particular oxygen and carbon is illustrated by the spectrum EDS of Figure 2. The analysis reveals the presence of oxygenated functional groups.

The ATR-FTIR spectra (Figure 3) indicates an intensive $\mathrm{OH}$ peak at $3337.26 \mathrm{~cm}^{-1}[3,2]$, the peaks alkyl at 2850.87 and $2918.03 \mathrm{~cm}^{-1}$ are assigned to aliphatic $\mathrm{C}-\mathrm{H}$ stretching bonds $[3,41]$, The bands, at 1616.28 and $1729.61 \mathrm{~cm}^{-1}$ due to the presence of $\mathrm{C}=\mathrm{O}$ bonds in carboxylate functional groups and carboxylic acid respectively $[3,41,42]$, the peak at 1424.49 , which is identical to the presence of $-\mathrm{C}-\mathrm{H}$ stretching in saturated aliphatic hydrocarbons (alkanes) with sp3-hybridizations [41], the band to $1374.23 \mathrm{~cm}^{-1}$, can be assigned to the vibration of elongation of the phenolic $\mathrm{OH}$ [2], the peak appeared to $1315.72 \mathrm{~cm}^{-1}$ due to $\mathrm{C}-\mathrm{O}$ stretching in esters, ether, phenol or carboxylic groups [42]. Finally the peaks at $1027.74-1157.27 \mathrm{~cm}^{-1}$ can be ascribed to $\mathrm{C}-\mathrm{N}$ stretching in aliphatic amines [41].

\section{Contact time}

The equilibrium time for the sorption of MB onto PBCF (Figure 4) was found to be $60 \mathrm{~min}$. Any intra particular diffusion was noted during the sorption experiments that should lead to a decrease in the slope between the fast initial and the equilibrium phase [3]. While a contact time of $60 \mathrm{~min}$ is quite sufficient for the sorption experiments following.

\section{Sorbent rate constant}

According to the literature, the first-order kinetic model given by Lagergren and the Ho's pseudo-second-order model are the most commonly used to provide the mechanism involved in the sorption process [43]. 


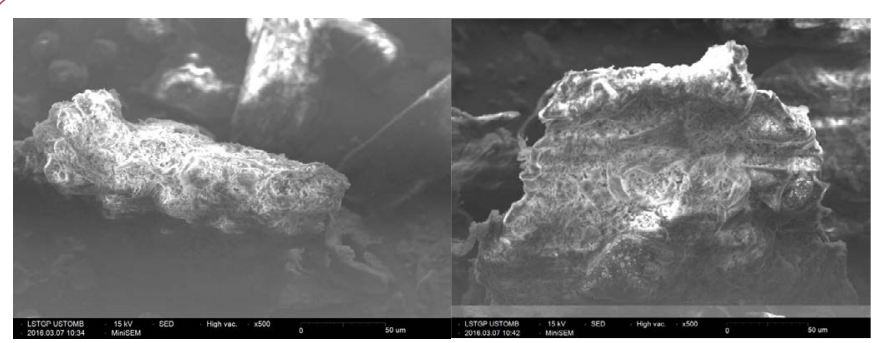

Figure 1 SEM image of the PBCF surface.

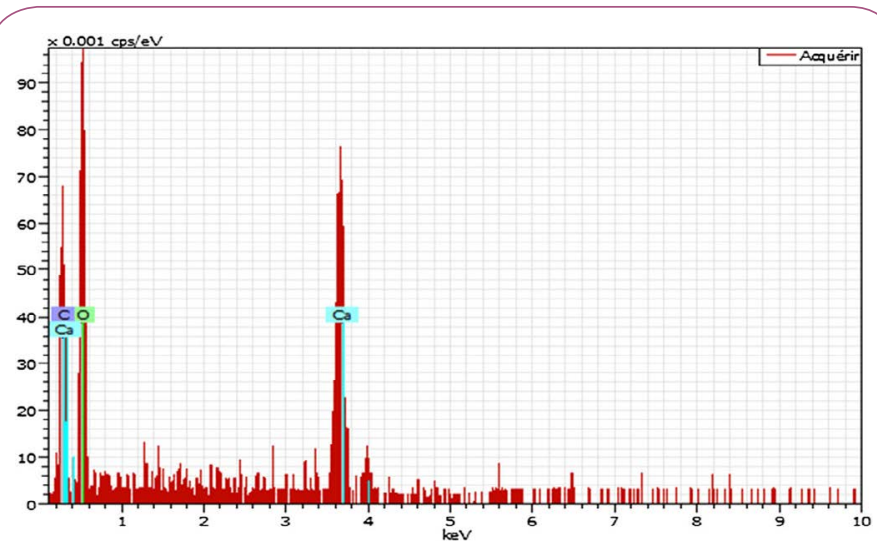

Figure 2 EDS microanalysis of the PBCF.

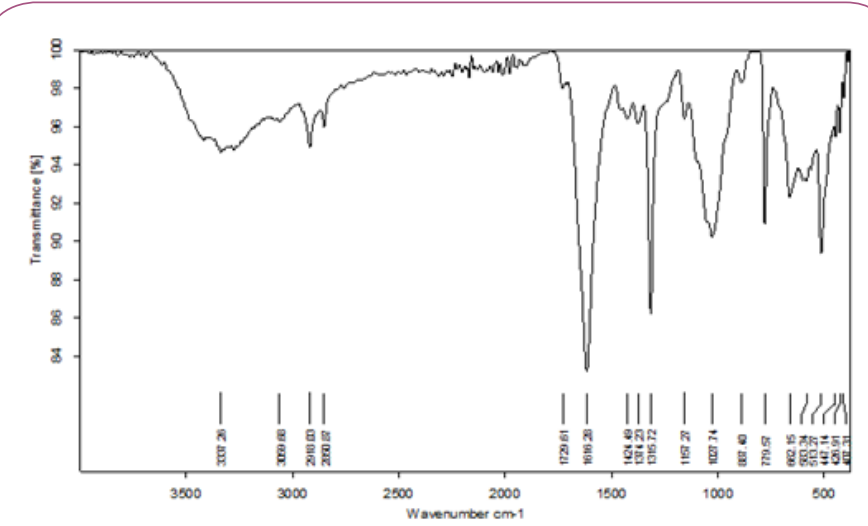

Figure 3 FTIR spectrum of PBCF.

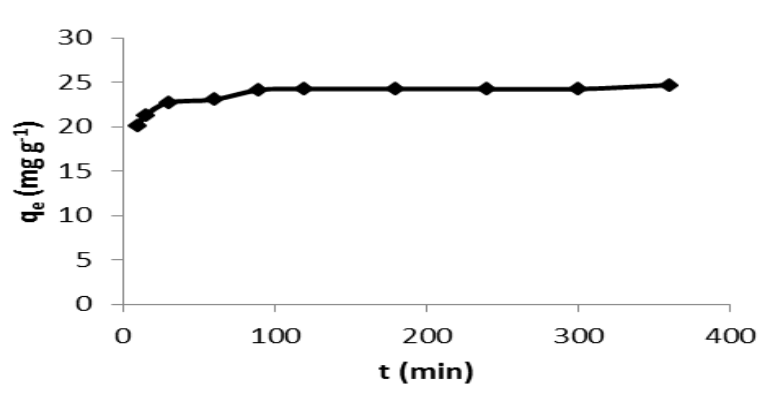

Figure 4 Effect of contact time on MB sorption by PBCF.
The Lagergren's first order model [43] is expressed by the following linear equation:

$\log \left(q_{e}-q_{t}\right)=\log q_{e}-\left(k_{1} / 2.303\right) t$

Were $\mathrm{q}_{\mathrm{e}}$ and $\mathrm{q}_{\mathrm{t}}$ are the amounts $\left(\mathrm{mg} \mathrm{g}^{-1}\right)$ of sorbed dye at instant $\mathrm{t}$ and at equilibrium respectively and $\mathrm{k}_{1}\left(1 \mathrm{~min}^{-1}\right)$ is the rate constant of sorption $\left(\mathrm{min}^{-1}\right)$.

The Ho's pseudo-second-order model [43] is expressed by the linear formula (3):

$t / q_{t}=1 / K_{2} q_{e}^{2}+\left(1 / q_{e}\right) t$

$\mathrm{K}_{2}\left(\mathrm{~g} \mathrm{mg}^{-1} \mathrm{~min}^{-1}\right)$ is the pseudo-second-order rate constant.

The results of this work did not fit the Largergern's first order model, however the good correlation of the plot (Figure 5) with the experimental results indicate that the sorption of and $M B$ Follow the pseudo second order kinetics. This model is frequently used in several works in the same field $[3,43]$.

The parameters of the Ho's pseudo-second-order model grouped in Table 1 shows a good determination coefficient value (0.99). Moreover the experimental and calculated values of the equilibrium removal capacity of $\mathrm{MB}$ onto $\mathrm{PBCF}$ were almost equivalent (qe $\approx$ qe calculated). Same phenomena for MB removal in batch system have been described in the literature [44].

\section{Effect of sorbent mass}

It was noted that the percentage of $M B$ removal increases according the amount of PBCF mass (Figure 6). This finding is justified by the high number of reactive vacant sites the mass transfer and concentration gradient is high. These favour the transfer of MB solute to the external surface of sorbent and increase on its removal percentage [41]. This in term of economic and view the important $\mathrm{MB}$ removal capacity, $0.1 \mathrm{~g}$ of sorbent was selected for the experiences those suites.

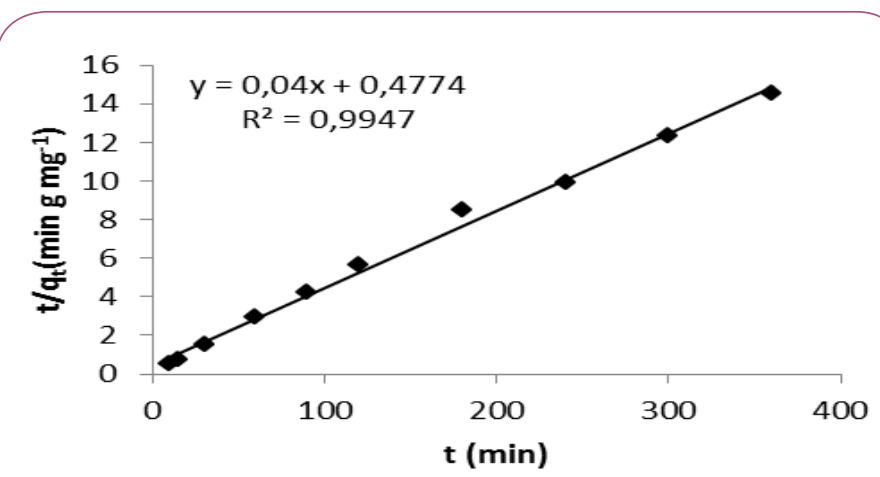

Figure 5 Pseudo-second-order model for MB removal by PBCF.

Table 1 Experimental and calculated rate constants for the second-order sorption.

\begin{tabular}{|c|ccc}
\hline $\mathrm{q}_{\mathrm{e}}\left(\mathrm{mg} \mathrm{g}^{-1}\right)$ & $\mathrm{K}_{2}\left(\mathrm{gm} \mathrm{g}^{-1} \mathrm{~min}^{-1}\right)$ & $\mathrm{q}_{\mathrm{e}}$ calculated $\left(\mathrm{mg} \mathrm{g}^{-1}\right)$ & $\mathbf{R}^{2}$ \\
\hline 24,6975 & 0,0034 & 25 & 0,9947 \\
\hline
\end{tabular}




\section{Effect of pH}

Figure 7 shows that the highest sorption capacities were recorded at $\mathrm{pH}$ greater than $\mathrm{pH}_{\mathrm{ZPC}}$ which gives a negative charge to the bio sorbent surface which leads to the increase of the fixation of the dye positively charged. However, the low values of this sorption capacity at $\mathrm{pH}$ less than 8 can be explained by the competition of protons with the solute at the available sites on the surface bio sorbent. The same interpretations have been reported by Bestani and Benderdouche et al onto an activated desert plant [37].

\section{Sorption isotherms}

Sorption isotherms data are an important study in the design of the sorption in batch systems.

The Freundlich and Langmuir mathematical models are the most frequently used to predict the equilibrium between the liquid phase (free solution) and the solid phase (adsorbent-attached solute) concentrations [45].

Freundlich isotherm model is represented by the following linear equation [46]:

\section{$\log q_{e}=1 / n \log C_{e}+\log K_{F}$}

Were $q_{e}\left(m g^{-1}\right)$ is the equilibrium sorption concentration of $M B$ per gram of PBCF; $C_{e}\left(\mathrm{mg} \mathrm{L}^{-1}\right)$ is the concentration of the solute in solution at equilibrium; $K_{F}$ and $n$ are Freundlich constants which are related to the sorption capacity and the intensity of sorption. In addition the values of $\mathrm{n}$ have a relation with favourability of the sorption process $[47,48]$. The value $1 / \mathrm{n}$ ranging between 0

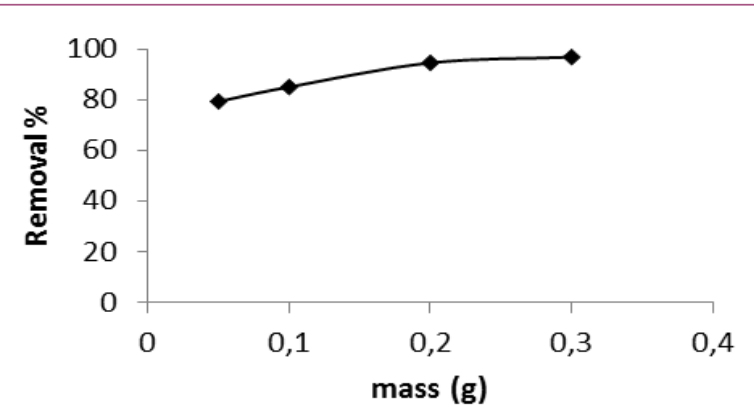

Figure 6 Dose PBCF effect on MB sorption.

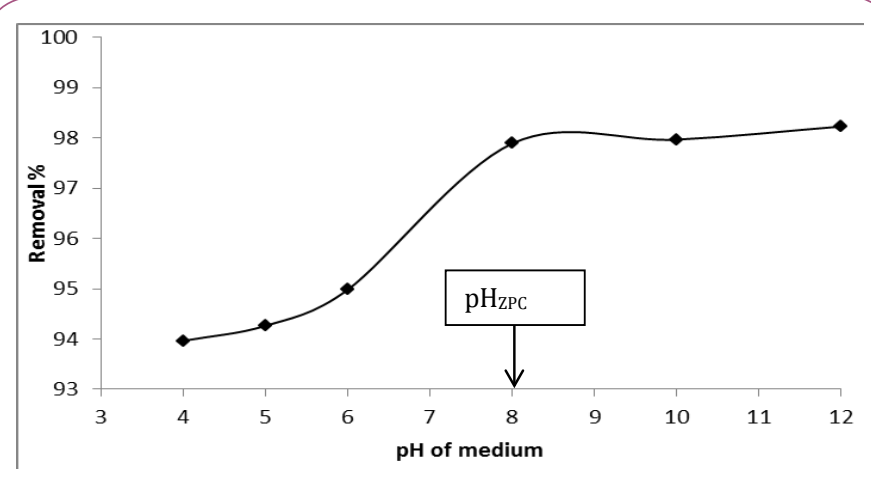

Figure $7 \mathrm{pH}$ effect on MB sorption onto PBCF. and 1 is a measure of sorption intensity or surface heterogeneity; over this value approach 0 the sorption is more heterogeneous [49].

Langmuir isotherm model is described by the following linear equation [50]:

$$
\mathrm{C}_{\mathrm{e}} / \mathrm{q}_{\mathrm{e}}=\mathrm{C}_{\mathrm{e}} / \mathrm{Q}_{\max }+1 / \mathrm{Q}_{\max } \mathrm{K}_{\mathrm{L}}
$$

$q_{e}\left(m g^{-1}\right)$ is the amount of solute adsorbed per unit dose of sorbent, $\mathrm{C}_{\mathrm{e}}\left(\mathrm{mg} \mathrm{L}^{-1}\right)$ is the dye equilibrium concentration, $\mathrm{Q}_{\max }(\mathrm{mg}$ $\left.\mathrm{g}^{-1}\right)$ is the sorption capacity, $\mathrm{K}_{\mathrm{L}}(\mathrm{L} / \mathrm{mg})$ is the Langmuir constant related to the adsorption energy. Moreover the equilibrium parameter (separation factor) $R_{L}$ is among the most important factors discussed in this paper, is calculated by the fallowing relation [51]:

$R_{L}=1 /\left(1+b C_{0}\right)$

Where $b$ is the Langmuir constant and $C_{0}\left(\mathrm{mg} \mathrm{L}^{-1}\right)$ is the highest solute concentration.

The isotherm to be either unfavorable $\left(R_{L}>1\right)$, linear $\left(R_{L}=1\right)$, favorable $\left(0<R_{L}<1\right)$ or irreversible $\left(R_{L}=0\right)$.

According to the plots (Figures $\mathbf{8}$ and 9) and the parameters of Freundlich and Langmuir grouped in Table 2, the correlation coefficients indicate a correct fit for both mathematical models ( 0.9958 and 0.9983 for Freundlich and Langmuir model respectively), however the Langmuir isotherm (Figure 9) fits better the experimental results. The value of $n(1.230)$ indicates that the sorption is favorable. Moreover the $R_{L}$ value between 0 and $1(0.0142)$ indicates that the sorption isotherm is favorable. The sorption capacity $\left(222.22 \mathrm{mg} \mathrm{g}^{-1}\right)$ of BM onto PBCF is better than those of many sorbent cited in the literature (Table 3 ).

\section{Thermodynamic quantities}

The thermal effect characterizing the bonding strength of the solute with active sites of the adsorbent was determined by the relationship between the distribution coefficient and the thermodynamic parameters.

The distribution coefficient was calculated by the following equation $[3,40]$ :

$$
\operatorname{Ln} K_{d}=(\Delta S / R)-(\Delta H \circ / R T)
$$

$R$, ideal gas constant. $T$, temperature $(K)$. $K_{d}$, distribution coefficient (amounts of removed MB per gram of material divided by its concentration in the liquid phase).

The plot of $\ln \left(K_{d}\right)$ versus $1000 / T$ gives a straight line, the slope and the intercept correspond to $\Delta H \circ / R$ and $\Delta S \circ / R$, respectively.

The plot of $\ln \left(K_{d}\right)$ versus $1000 / T$ for MB sorption is represented in Figure 10, and the thermodynamic quantities are regrouped in Table 4.

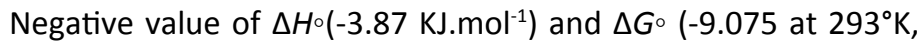
-9.25 at $303^{\circ} \mathrm{K}$ and $-9.43 \mathrm{KJ} \mathrm{mol}^{-1}$ at $313^{\circ} \mathrm{K}$ ) indicate that the sorption process was exothermic and almost spontaneous respectively. Positive value of $\Delta S^{\circ}\left(17.76 \mathrm{~J} \mathrm{~mol}^{-1} \mathrm{~K}^{-1}\right)$ demonstrate the presence of a disorder at the solid-liquid interface during the sorption of the MB on the substrate [3]. 


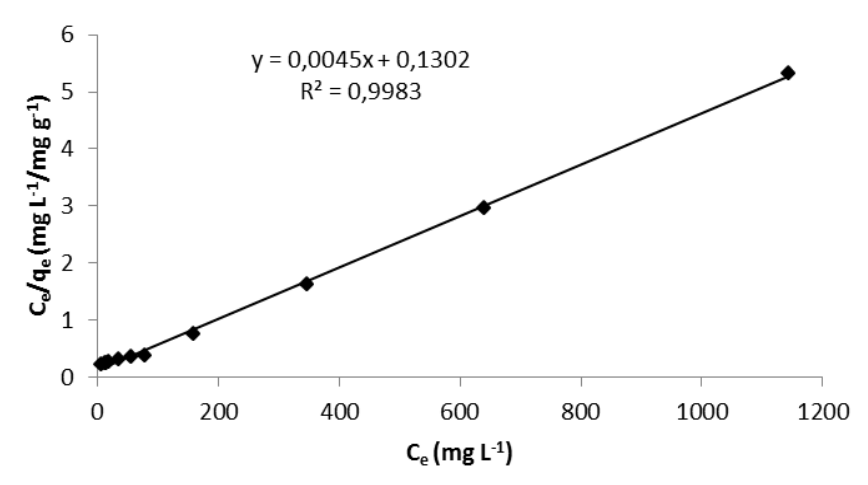

Figure 8 Langmuir isotherm of MB removal by PBCF.

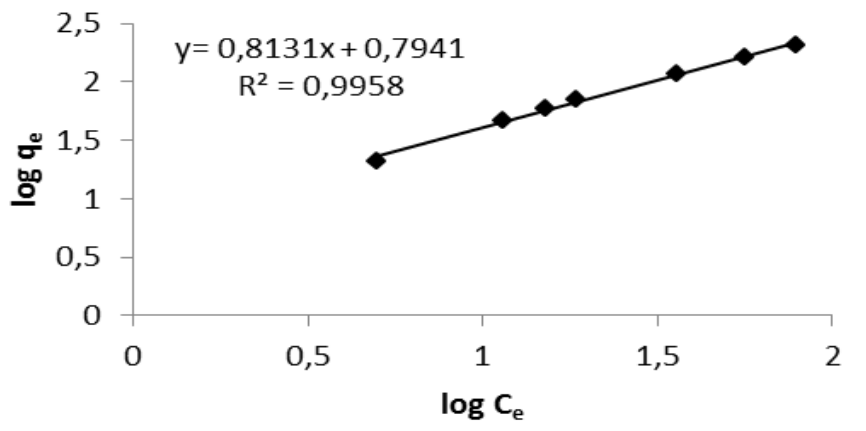

Figure 9 Freundlich isotherm of MB removal by PBCF.

Table 2 Langmuir and Freundlich constants for Methylene Blue sorption on PBCF.

\begin{tabular}{|c|c|c|c|c|c|c|c|}
\hline \multicolumn{3}{c}{ Langmuir constants } & \multicolumn{4}{c}{ Freundlich constants } \\
\hline $\mathrm{Q}_{\max }\left(\mathrm{mg} \mathrm{g}^{-1}\right)$ & $\mathrm{K}_{\mathrm{L}}\left(\mathrm{L} \mathrm{mg}^{-1}\right)$ & $\mathrm{R}^{2}$ & $\mathrm{R}_{\mathrm{L}}$ & $1 / \mathrm{n}$ & $\mathrm{n}$ & $\mathrm{K}_{\mathrm{F}}$ & $\mathrm{R}^{2}$ \\
\hline 222,2222 & 0,0345 & 0,9983 & 0,0142 & 0,813 & 1,230 & 2,212 & 0,9958 \\
\hline
\end{tabular}

\section{Conclusion}

This study showed that the Prickly bark of cactus fruit is considered as a low cost natural sorbent. A contact time of $60 \mathrm{~min}$ is quite sufficient for the sorption experiments. The sorption data and kinetic of Methylene blue onto PBCF fitted well the Ho's pseudosecond-order model with a good determination coefficient. The mathematical Langmuir and Freundlich models showed that the sorption data of Methylene blue onto the prepared bio-sorbent is favorable with a better sorption capacity $222.22 \mathrm{mg} \mathrm{g}^{-1}$ ), than those of many sorbent cited in the literature. The thermodynamic parameters and experimental data revealed that the sorption was, spontaneous, exothermic and feasible. EDS, FTIR, and iodine number studies indicate the presence of oxygenated functional groups with a high surface area. The percentage of methylene blue fixation increases according the amount of PBCF mass, this explained by the high number of reactive vacant sites the mass transfer and concentration gradient is high.
The highest sorption capacities were recorded at $\mathrm{pH}$ greater than $\mathrm{pH}_{\mathrm{ZPC}}$ which gives a negative charge to the bio sorbent surface which leads to the increase of the fixation of the dye positively charged.

Table 3 Comparison of sorption capacity of Methylene Blue onto activated carbons and other low-cost sorbents.

\begin{tabular}{|c|c|c|}
\hline Sorbent & $\begin{array}{c}\text { Sorption capacity } \\
\qquad\left(\mathrm{mg} \mathrm{g}^{-1}\right)\end{array}$ & Reference \\
\hline inactivated desert plant & 23 & [37] \\
\hline Pyrolized desert plant & 53 & [37] \\
\hline Chemically activated desert plant & 130 & [37] \\
\hline Commercial activated carbon & 200 & [37] \\
\hline Black stone cherries & 321,75 & [52] \\
\hline Walnut shell & 315 & [53] \\
\hline Oil palm shell & 243,90 & [54] \\
\hline Hazelnut husks & 204 & [55] \\
\hline Plant leaf powder & 61,22 & [56] \\
\hline Wood apple rind & 40 & [57] \\
\hline Caulerpa lentillifera & 417 & [58] \\
\hline Sargassum muticum & 279,20 & [59] \\
\hline Dead macro fungi (F) & 232,73 & [60] \\
\hline Dead macro fungi (P) & 201,38 & [60] \\
\hline Algae Gelidium & 171 & [61] \\
\hline Algal waste & 104 & [61] \\
\hline Composite material & 74 & [61] \\
\hline Duckweed & 144,93 & [62] \\
\hline Green alga & 40,20 & [63] \\
\hline The brown alga & 38,61 & [64] \\
\hline PBCF & 222,22 & this study \\
\hline
\end{tabular}

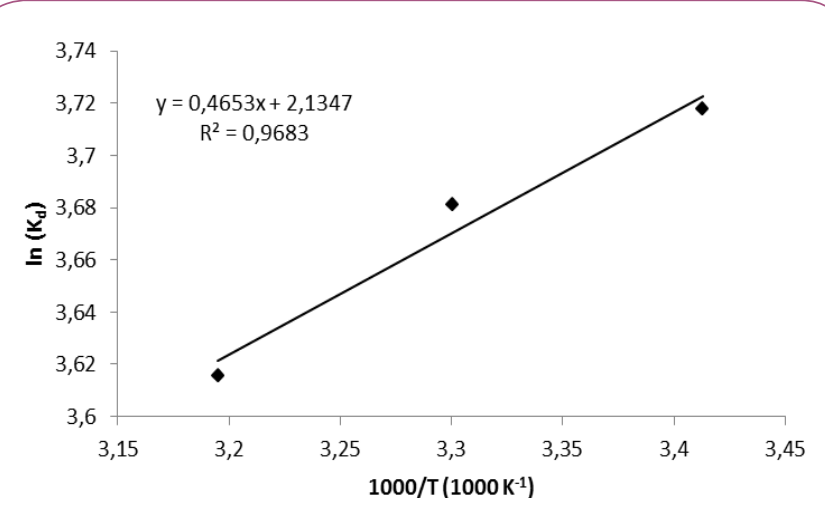

Figure 10 Plot of In $\mathrm{K}_{d}$ vs. 1000/T for MB removal by PBCF.

Table 4 Thermodynamic parameters for Methylene Blue sorption on PBCF.

\begin{tabular}{lllll}
$\Delta \mathrm{S} \circ\left(\mathrm{J} \mathrm{mol}^{-1} \mathrm{~K}^{-1}\right)$ & $\Delta \mathrm{H} \circ\left(\mathrm{kJ} \mathrm{mol}^{-1}\right)$ & \multicolumn{3}{l}{$\Delta \mathrm{G} \circ\left(\mathrm{kJ} \mathrm{mol}^{-1}\right)$} \\
\hline 17,76 & $293^{\circ} \mathrm{K}$ & $303^{\circ} \mathrm{K}$ & $313^{\circ} \mathrm{K}$ \\
\hline & $-3,87$ & $-9,07$ & $-9,25$ & $-9,43$
\end{tabular}




\section{References}

1 Yagub MT, Sen TK, Afroze S, Ang HM (2009) Dye and its removal from aqueous solution by adsorption: A review. Adv in Coll and Intere Sci 209: 172-184.

2 Sakr F, Sennaoui A, Elouardi M, Tamimi M, Assabbane A (2015) Adsorption study of Methylene Blue on biomaterial using cactus. J Mater Environ Sci 6: 397-406.

3 Aziz A, Ouali MS, Elandaloussi E, De Menorval LC, Lindheimer M (2009) Chemically modified olive stone: A low-cost sorbent for heavy metals and basic dyes removal from aqueous solutions. J Hazard Mater 163: 441-447.

4 Esmaili S, Nasseri SR, Atash-Dehghan R (2003) Adsorption of Lead and Zinc ions from aqueous solutions by Volcanic Ash Soil (VAS) Proc of the 8th Intern Confon Envir Sci and Technol 8-10.

5 Albert M, Lessin MS, Gilchrist BF (2003) Methylene blue: dangerous dye for neonates. J Pediatr Surg 38: 1244-1245.

6 Gillman PK (2011) CNS toxicity involving methylene blue: the exemplar for understanding and predicting drug interactions that precipitate serotonin toxicity. J Psychopharmacol 25: 429-436.

7 Belaroui K, Seghier A, Hadjel M (2014) Synthesis of activated carbon based on apricot stones for wastewater treatment. Desalin Water Treat 52: 1422-1433.

8 Kovalova L, Hansruedi S, Von Gunten U, Eugster J, Hagenbuch M, et al. (2013) Elimination of micropollutants during post-treatment of hospital wastewater with powdered activated carbon, ozone, and UV. Sci Technol 47: 7899-7908.

9 Ruhl AS, Zietzschmann F, Hilbrandt I, Meinel F, Altmann J, et al. (2014) Targeted testing of activated carbons for advanced wastewater treatment. J Chem Eng 257: 184-190.

10 Khandegar V, Saroha AK (2013) Electrocoagulation for the treatment of textile industry effluente A review. J Environ Manag 128: 949-963.

11 Liang CZ, Sun SP, Li FY, Ong YK, Chung TS (2014) Treatment of highly concentrated wastewater containing multiple synthetic dyes by a combined process of coagulation/flocculation and nanofiltration. J Membr Sci 469: 306-315.

12 Ge Q, Wang P, Wan C, Chung TS (2012) Polyelectrolyte-promoted forward osmosisemembrane distillation (FOeMD) hybrid process for dye wastewater treatment. Environ Sci Technol 46: 6236-6243.

13 Zhao P, Gao B, Xu S, Kong J, Ma D, et al. (2015) Polyelectrolytepromoted forward osmosis process for dye wastewater treatmentExploring the feasibility of using polyacrylamide as draw solute. Chem Eng J 264: 32-38.

14 Punzi M, Nilsson F, Anbalagan A, Svensson BM, Jeonsson K, et al. (2015) Combined anaerobiceozonation process for treatment of textile wastewater: removal of acute toxicity and mutagenicity. J Hazard Mater 292: 52-60.

15 Aouni A, Fersi C, Cuartas-Uribe B, Bes-Pía A, Alcaina-Miranda MI, et al. (2012) Reactive dyes rejection and textile effluent treatment study using ultrafiltration and nanofiltration processes. Desalination 297: 87-96.

16 Ong YK, Li FY, Sun SP, Zhao BW, Liang CZ, et al. (2014) Nanofiltration hollow fiber membranes for textile wastewater treatment: lab-scale and pilotscale studies. Chem Eng Sci 114: 51-57.

17 Zhang L, Xu L, He J, Zhang (2014) Preparation of Ti/SnO 2-Sb electrodes modified by carbon nanotube for anodic oxidation of dye wastewater and combination with nanofiltration. Electrochim J Electrochim Acta 117: 192-201.

18 Gupta VK, Jain R, Mittal A, Saleh TA, Nayak A, et al. (2012) Photocatalytic degradation of toxic dye amaranth on TiO 2/UV in aqueous suspensions. Mater Sci Eng 32: 12-17.

19 Wang A, Li X, Zhao Y, Wu W, Chen J (2014) Preparation and characterizations of $\mathrm{Cu} 2 \mathrm{O} /$ reduced graphene oxide nanocomposites with high photo-catalytic performances. Powder Technol 261: 42-48.

20 Bhatnagar R, Joshi H, Mall ID, Srivastava VC (2014) Electrochemical treatment of acrylic dye-bearing textile wastewater: optimization of operating parameters. Desalination Water Treat 52: 111-122.

21 Aquino JM, Rocha-Filho RC, Ruotolo LA, Bocchi N, Biaggio SR (2014) Electrochemical degradation of a real textile wastewater using b-PbO2 and DSA ${ }^{\oplus}$ anodes. Chem Eng J 251: 138-145.

22 Ghosh A, Dastidar MG, Sreekrishnan TR (2014) Biosorption and biodegradation of chromium complex dye using Aspergillus species. J of Hazar Toxic Radioact Waste 18: 4014-4022.

23 Choi Y, Park B, Cha DK (2015) Enhancing biological treatment of dye wastewater with zero-valent iron. Korean J Chem Eng 32: 1812-1817.

24 Bilal M, Asgher M, Parra Saldivar S, Hu H, Wang W, et al. (2017) Immobilized ligninolytic enzymes: An innovative and environmental responsive technology to tackle dye-based industrial pollutants-A review. Science of The Total-Environ 576: 646-659.

25 Chatha SAS, Asgher M, Iqbal HMN (2017) Enzyme-based solutions for textile processing and dye contaminant biodegradation-a review. Environ Sci Pollut Res 1-14.

26 Bilal M, Asgher M, Iqbal HMN, Hu H, Zhang X (2017) Bio-based degradation of emerging endocrine-disrupting and dye-based pollutants using cross-linked enzyme aggregates. Environ Sci Pollut Res.

27 Bilal M, Iqbal HMN, Hu H, Wang W, Zhang X (2017) Development of horseradish peroxidase-based cross-linked enzyme aggregates and their environmental exploitation for bioremediation purposes. J of Environ Manag 188: 137-143.

28 Bilal M, Iqbal HMN, Hu H, Wang W, Zhang X (2017) Enhanced biocatalytic performance and dye degradation potential of chitosanencapsulated horseradish peroxidase in a packed bed reactor system. Sci of The Total Environ 575: 1352-1360.

29 Asgher M, Shah SAH, Iqbal HMN (2016) Statistical correlation between ligninolytic enzymes secretion and Remazol Brilliant Yellow3GL dye degradation potential of Trametes versicolor IBL-04 Water Environment Research 88: 338-345.

30 Chatha SAS, Asgher M, Iqbal HMN, Ali S (2016) A Novel Enzymatic Stripping of $\mathrm{Cl}$ Reactive Black B Dyed Knitted Textiles Fabric as an Environmentally Responsible Technology. Electronic Journal of Biology 12: 276-281.

31 Asgher M, Yasmeen K, Iqbal HMN (2013) Enhanced decolorization of Solar brilliant red 80 textile dye by an indigenous white rot fungus Schizophyllum commune IBL-06. Saudi J of biological Sci 20: 347-352.

32 Rafatullah M, Sulaiman O, Hashim R, Ahmad A (2010) Adsorption of methylene blue on low-cost adsorbents: a review. J Hazard Mater 177: 70-80.

33 Ekrami E, Dadashian F, Arami M (2015) Adsorption of methylene blue by waste cotton activated carbon: equilibrium, kinetics, and thermodynamic studies. Desalination Water Treat 1-11.

34 Abdel-Ghani NT, El-Chaghaby GA, Zahran EM (2015) 
Pentachlorophenol (PCP) adsorption from aqueous solution by activated carbons prepared from corn wastes. Int J Environ Sci Technol 12: 211-222.

35 Li J, Ng DH, Song P, Kong C, Song Y, et al. (2015) Preparation and characterization of high-surface-area activated carbon fibers from silkworm cocoon waste for congo red adsorption. Biomass Bioenergy 75: $189-200$.

36 Malkoc E, Nuhoglu Y (2006) Removal of $\mathrm{Ni}(\mathrm{II})$ ions from aqueous solutions using waste of tea factory: Adsorption on a fixed-bed column. J Hazard 135: 328-336.

37 Bestani B, Benderdouche N, Benstaali B, Belhakem M, Addou A (2008) Methylene blue and iodine adsorption onto an activated desert plant. Bioresour Technol 99: 8441-8444.

38 ASTM D4607-94 (1999) Standard Test Method for Determination of lodine Number of Activated Carbon.

39 Liu H, Ning W, Cheng P, Zhang J, Wang Y, et al. (2013) Evaluation of animal hairs-based activated carbon for sorption of norfloxacin and acetaminophen by comparing with cattail fiber-based activated carbon. J Anal Appl Pyrolysis 101: 156-165.

40 Shrestha S, Son G, Lee SH, Lee TG (2013) Isotherm and thermodynamic studies of Zn (II) adsorption on lignite and coconut shell-based activated carbon fiber. Chemosphere 92: 1053-1061.

41 Ghaedi M, Shojaeipour E, Ghaedi AM, Reza S (2015) Isotherm and kinetics study of malachite green adsorption onto copper nanowires loaded on activated carbon: Artificial neural network modeling and genetic algorithm optimization. Mol Biomol Spectrosc 142: 135-149.

42 Liua H, Gaoa Q, Daib P, Zhanga J, Zhanga C (2013) Preparation and characterization of activated carbon from lotus stalk with guanidine phosphate activation: Sorption of Cd(II). J Anal Appl Pyrolysis 102: 7-15.

43 Ho YS, McKay G (1999) Pseudo-second order model for sorption processes, Biochem 34: 451-465.

44 Kavitha D, Namasivayam C (2007) Experimental and kinetic studies on methylene blue adsorption by coir pith carbon. Bioresour Technol 98: 14-21.

45 Benderdouche N, Bestani B, Benstaali B, Derriche Z (2003) Enhancement of the adsorptive properties of a desert Salsola vermiculata species. Ads Sci \& Tech 221: 739-750.

46 Freundlich HMF (1906) Over the adsorption in solution. J Phys Chem 57: 385-470.

47 Pollard SJT, Sollars CJ, Perry R (1991) A low cost adsorbent from spent bleaching earth. I-the selection of an activation procedure. J Chem Technol Biotechnol 50: 265-275.

48 Yao Y, Xu F, Chen M, Xu Z, Zhu Z (2010) Adsorption behavior of methylene blue on carbon nanotubes. Bioresour Technol 101: 30403046.

49 Haghseresht F, Lu G (1998) Adsorption characteristics of phenolic compounds onto coal-reject-derived adsorbents. Energy Fuels 12: 1100-1107.
50 Langmuir I (1918) The adsorption of gases on plane surfaces of glass, mica and platinum. J Am Chem Soc 40: 1361-1403.

51 Hall K, Eagleton L, Acrivos A, Vermeulen T (1966) Pore-and soliddiffusion kinetics in fixed-bed adsorption under constant-pattern conditions. Ind Eng Chem Fundam 5: 212-223.

52 Rodríguez Arana JMR, Mazzoco RR (2010) Adsorption studies of methylene blue and phenol onto black stone cherries prepared by chemical activation. J Hazard Mater 180: 656-661.

53 Yang J, Qiu K (2010) Preparation of activated carbons from walnut shells via vacuum chemical activation and their application for methylene blue removal. Chem Eng J 165: 209-217.

54 Tan I, Ahmad A, Hameed B (2008) Adsorption of basic dye using activated carbon prepared from oil palm shell: batch and fixed bed studies, Desalination 225: 13-28.

55 Ozer C, Imamoglu M, Turhan Y, Boysan F (2012) Removal of methylene blue from aqueous solutions using phosphoric acid activated carbon produced from hazelnut husks., Toxicol Environ Chem 94: 1283-1293.

56 Gunasekar V, Ponnusami V (2012) Kinetics, equilibrium, and thermodynamic studies on adsorption of methylene blue by carbonized plant leaf powder. J Chem 13: 1-6.

57 Malarvizhi R, Ho YS (2010) The influence of $\mathrm{pH}$ and the structure of the dye molecules on adsorption isotherm modeling using activated carbon. Desalination 264: 97-101.

58 Marungrueng K, Pavasant P (2007) High performance biosorbent (Caulerpa lentillifera) for basic dye removal. Bioresour Technol 98: 1567-1572.

59 Rubin E, Rodriguez P, Herrero R, Cremades J, Barbara I (2005) Removal of methylene blue from aqueous solutions using as biosorbent Sargassum muticum: an invasive macroalga in Europe. $J$ Chem Technol Biotechnol 80: 291-298.

60 Maurya NS, Mittal AK, Cornel P, Rother E (2006) Biosorption of dyes using dead macro fungi: effect of dye structure, ionic strength and pH. Bioresour Technol 97: 512-521.

61 Vilar VJP, Botelho C, Boaventura RAR (2007) Methylene blue adsorption by algal biomass based materials: biosorbents characterization and process behaviour. J Hazard Mater 147: 120-132.

62 Waranusantigul $\mathrm{P}$, Pokethitiyook $\mathrm{P}$, Kruatrachue $\mathrm{M}$, Upatham US (2003) Kinetics of basic dye (methylene blue) biosorption by giant duckweed (Spirodela polyrrhiza). Environ Pollut 125: 385-392.

63 El Sikaily A, Khaled A, Nemr AE, Abdelwahab O (2006) Removal of methylene blue from aqueous solution by marine green alga Ulva lactuca. Chem Ecol 22: 149-157.

64 Caparkaya D, Cavas L (2008) Biosorption of methylene blue by a brown alga Cystoseira barbatula Kutzing. Acta Chim Slov 55: 547-553. 